McGill Journal of Education

Revue des sciences de l'éducation de McGill

FINDING AUTHENTICITY THROUGH STORYTELLING:

REFLECTIONS FROM A HIGH SCHOOL CLASSROOM

ACCÉDER À L'AUTHENTICITÉ PAR LA COMMUNICATION

NARRATIVE : RÉFLEXIONS D’UNE CLASSE AU SECONDAIRE

Joey Yung-Jun Liu

Volume 54, Number 3, Fall 2019

URI: https://id.erudit.org/iderudit/1069775ar

DOI: https://doi.org/10.7202/1069775ar

See table of contents

Publisher(s)

Faculty of Education, McGill University

ISSN

1916-0666 (digital)

Explore this journal

Cite this note

Liu, J.-J. (2019). FINDING AUTHENTICITY THROUGH STORYTELLING: REFLECTIONS FROM A HIGH SCHOOL CLASSROOM. McGill Journal of Education / Revue des sciences de l'éducation de McGill, 54(3), 670-679. https://doi.org/10.7202/1069775ar

\section{Article abstract}

This piece is an auto-biographical reflection on my year-long experience creating a new course called Oral Interpretations and Expressions. Teaching the course allowed me to find an authenticity and identity in my work, which had been eluding me as I conformed to administrative norms in education. Through the practice of story-telling in spoken word poetry, my students and I found healing and transformation. This note invites the reader to consider how story-telling might be used in their own teaching spaces to empower a deeper connection to authenticity within themselves and their students.
(C) Faculty of Education, McGill University, 2020
This document is protected by copyright law. Use of the services of Érudit (including reproduction) is subject to its terms and conditions, which can be viewed online.

https://apropos.erudit.org/en/users/policy-on-use/ 


\title{
FINDING AUTHENTICITY THROUGH STORY- TELLING: REFLECTIONS FROM A HIGH SCHOOL CLASSROOM
}

JOEYYUNG-JUN LIU Chapman University

\begin{abstract}
This piece is an auto-biographical reflection on my year-long experience creating a new course called Oral Interpretations and Expressions. Teaching the course allowed me to find an authenticity and identity in my work, which had been eluding me as I conformed to administrative norms in education. Through the practice of story-telling in spoken word poetry, my students and I found healing and transformation. This note invites the reader to consider how story-telling might be used in their own teaching spaces to empower a deeper connection to authenticity within themselves and their students.
\end{abstract}

\section{ACCÉDER À L'AUTHENTICITÉ PAR LA COMMUNICATION NARRATIVE : RÉFLEXIONS D'UNE CLASSE AU SECONDAIRE}

RÉSUMÉ. Cet article expose les réflexions tirées de l'expérience vécue lors de la création d'un nouveau cours intitulé Oral Interpretations and Expressions. Enseigner ce cours m'a permis d'accéder à une forme d'authenticité et d'identité qui m'échappait dans ma vie professionnelle lorsque que je me conformais aux normes administratives en éducation. Grâce à la communication narrative sous la forme de poésie parlée, mes étudiants et moi avons découvert la guérison et la transformation. Cette note encourage le lecteur à évaluer de quelle manière la communication narrative peut être utilisée dans leur pratique enseignante pour permettre une connexion plus profonde à l'authenticité, en eux et chez leurs étudiants.

\footnotetext{
$W_{\text {hen I entered my teaching career as a secondary language arts teacher, I }}$ made demands of myself to be loving, committed, patient, effective, creative, and authentic. Over my years in the classroom, striving for authenticity has been my tireless endeavor. Too often, though, I feel that the love I profess for my students is far more illusory than real. With the demands placed on me by my administration and district, I have struggled to reconcile what I believe to be the best for myself and my students. Challenging those demands has led to frequent insecurity in my job position, and, over time, I have noticed a watering down of my teaching practice as I grow increasingly accustomed to jumping through bureaucratic hoops.
} 
Engaging in critical reflection has felt like an unshakeable curse: I am afflicted by the discomfort of knowing that what I am doing may not be authentic enough to someone in the room, even if, most often, that person is me. Yet grappling with authenticity, and then surrendering to moments just as they are, has helped me honour some of the most powerful experiences in my teaching life. Authenticity, for me, is the sense of harmony and ease I experience when my actions and words are aligned with my desires, beliefs, and identity. Authenticity as an educator is similar to Freire's (2005) idea of coherence, in which a teacher's words and actions do not contradict one another. For my students to truly learn from me and with me, I needed to allow a deeper, more honest expression of myself to emerge. Moments of authenticity can be raw and uncomfortable. The impact of those moments with my students, when they occur, are whole and profound. As we embarked on a year-long exploration of story-telling, courageous conversations, celebration of vulnerability, and surrendering to an uncharted and interconnected process of creation and human expression, I made my peace with my quest for authenticity. This note is an account of that quest.

\section{TEACH WHAT YOU WANT TO LEARN}

The opportunity for me to create a new elective course allowed me to deeply grapple with finding authenticity. My principal asked me to teach a new visual and performing arts class with an emphasis on language arts. I chose a course in the school catalog called Oral Interpretations and Expressions because it most resembled the type of units I would design, ones that explored creative writing, poetry, and the power of oral messages. I have always looked for opportunities to incorporate dialogue and story-telling into my curriculum because I share Margaret Wheatley's (2002) belief that "human conversation is the most ancient and easiest way to cultivate conditions for change -personal change, community, and organizational change" (p. 3). At the time, many of my students were showing an interest in developing their creative writing and public speaking skills.

I didn't realize how deeply I would have to engage with vulnerability. I was engulfed with excitement, blind to any risk. My joy lay in the opportunity to break free of the restrictions and expectations that had slowly drained my enthusiasm in core content classes. Even if I was only one step ahead of my students in learning the material, I knew that I would be learning something meaningful and interesting to me, that the journey would be worth it.

\section{STORY-TELLING}

I began the class with story-telling. Paolo Freire (1996) wrote that "education is suffering from narration sickness" (p. 52), crushed by a dominant narrative that does not reflect the truths of most learners. I was convinced that the 
story-telling I built into every class I taught was part of the remedy to the sickness we feel when the story of school doesn't look or sound like us. In the course, I asked students to consider the oral traditions of their ancestors and to dig deeper into uncovering their own identities. I asked them to write and present on their culture, however they chose to define it. I wanted my students to discover not only that stories make up our understanding of the world, but also to identify what those stories were and whose voice was telling each story. Ultimately, I wanted my students to decide who they were as storytellers and what stories they would choose to tell themselves.

I noticed a considerable amount of discomfort as they struggled to define their identity in writing. At the time, I didn't have the tools to help them through their emotions, since I was still grappling with my own reservations about how vulnerable I would allow myself to be. Though I felt confident of my story-teller's voice among an audience of peers, I had not yet reconciled my story-teller identity with my position as a teacher-which always seemed to be inhibited by administrative regulation. I wasn't sure what stories I could tell, if any, within a classroom.

It wasn't until we began writing our stories in poetry that I realized the extent to which I was holding back. I was choosing to avoid vulnerability and, ultimately, defaulting into the inauthenticity that I had been so excited to escape when I first began the course. My students were more interested in exploring poetry-specifically slam poetry-than anything else. Yet I was not prepared to teach them much about the medium. I had never been a slam poet before. In fact, it had been years since I had even written poetry for myself. Ashamed and nervous, I receded deeper into inauthenticity as I avoided admitting my lack of experience with the content. I faked a command over poetry writing exercises liberally borrowed from spoken word curriculum books, and I did the same with the performance tips I gleaned from slam poetry performance videos on YouTube.

I mastered the charade enough to keep the class going, but, once again, when faced with moments of despair from students who were breaking down under the weight of their own vulnerability or confronted with resistance from students who were too uncomfortable to dig deeper into their own secret stories, I had no authentic wisdom to offer them. I was still writing poems addressed to large, impersonal audiences. I never exposed memories. I never wrote to heal from my own wounds. My secrets stayed well hidden in my closet. I wouldn't even allow them to touch the surface of paper for my own eyes to read.

Yet I continued to ask my students to explore their identities and lived experiences and to write their truths unashamedly. Somehow, despite my own hypocrisy, my students took the lead in boldly breaking the barrier of 
personal truth-telling. Perhaps this is because they were more fearless than I. Perhaps they felt they had less to lose. Perhaps it was because I had held an unwavering expectation that, if I loved them and cheered for them enough, they would speak their truths in ways that I was not ready to do. As Jeff Duncan-Andrade (2007) explains, "the people that we love can demand levels of commitment from us that defy even our own notions of what we are capable of" (p. 634). In this instance, faith and love worked. My students overcame their fears and committed themselves to a process of uncovering their truths.

The first poems my students wrote in this course were response poems to the oral traditions they uncovered in their personal inquiry of their own culture. We allowed space for culture to be defined individually. We came to realize that, to be authentic, we also needed to allow space for each of us to feel differently about our connection to our culture, or lack thereof. Maya's (2016) poem was especially memorable for all of us in that class. In her voice, we heard a break and an emotion that many of us were still keeping at bay. Her poem invited us into her conflict with her own culture and stories of origin. The authenticity in her voice demanded that we listen and consider our own truths a little more closely.

\section{Maya's Culture Response Poem}

There are empty spaces in this body where an origin story is supposed to be.

I have never been enough of one thing

to take a pin to a map and tell you exactly where this skin was derived from.

I never been enough of one thing

for it to be wholesome enough to make a fist clasped around it and show you.

I have never been enough of one thing

because when my mother left the ice caps for my father,

and then when my mother left me to go back home,

I was too small to know that the color of this skin and these almond shaped eyes spell out Inuit.

I was too small to know that it equates to anything more than the packages of whale meat received from the family up north,

anything more than my mother's bloody fingers crafting fish bone jewelry.

I have never been enough of one thing

because when my mother left the ice caps,

she came with but a single thread wrapped around her pinky finger 
all the way from here to Nome, Alaska, and that's exactly how fragile the connection feels.

So I'm not enough of one thing

because when my mother left me to go back,

she took that single thread and raveled it around her pinky finger until she was home,

and maybe that's why I don't know anything,

my mother took the whole origin story, got up, moved away, followed her thread back home,

forgot about me, never said goodbye, died, and took the whole damn thing with her.

And so there are empty spaces in this body where an origin story is supposed to be.

Maya-Jacinta Birdie Griego, age $17(2016)^{1}$

\section{A PEDAGOGY OF LOVE}

I had come into teaching proclaiming that love was the way; teaching for me was always an act of love (Darder, 2011). And yet, in my quiet, inner dialogue with my critical consciousness, I battled doubts which questioned if love was enough, if my loving students was self-serving, if love for other people's children could be authentic, and if creating spaces of love in places where love was a scarce resource was even possible. Despite these inner insecurities, I couldn't shake my need to make love fit in my pedagogy and in daily classroom happenings. Sometimes, that meant simply drowning out my doubts with bold proclamations to my students about love and the transformational, healing power I believed it to carry.

In Oral Expressions, this love transformed us. My students began to believe that there was enough love in that room for them to start putting their fears on paper. Soon, they began to trust that love was enough for them to speak their secrets aloud. Sometimes students would break down and cry as they began to test the space of vulnerability outside their comfort zone. In these moments, I would simply say, "Whoever needs to show him or her love right now, go do that," and at least five or six students would rush up from their seats to embrace the crying student in a group hug. I showed my students a ritual I had learned while volunteering in schools in Tanzania called "pasha." Whenever a student was brave enough to answer aloud in front of the class, we would rub our hands together and say, "pasha, pasha, pasha," and then hold our hands out in front of our bodies in the direction of the student to indicate making a fire and sending it over to them. When I brought this 
practice into my Oral Expressions class, the metaphorical fire evolved from one of reward for volunteering an answer into a fire of love and encouragement whenever anyone found themselves in a moment of vulnerability while in front of the class.

\section{GET FREE}

During these tender and surprising moments, I privately approached my own fear of vulnerability. As I continued to lead students in writing exercises and to write alongside them, I challenged myself to quietly listen to the secret stories that were asking me to be acknowledged and honored. I borrowed a phrase from a fellow poetry teacher to "get free," which meant to allow whatever word, memory, thought, or feeling that passed through our heads and hearts to flow through our hands onto our papers. We would honor these memories and feelings, developing them into entire stories within our poetry. We first worked the stories out in our own consciousness, then we invited our learning communities and audiences into our process when we were ready. We learned to trust this process and the love we held in this space.

Eventually, the journey I was traveling on with my students brought me the courage to face my fears of vulnerability. I realized that, as a teacher, I am first a human. As a human, I am no different from my students. I am here to learn too. I began to write and share poems that helped me process grief, anger, confusion, and trauma. I waited to share the poems with my students until I knew I was free, not needing validation or comfort.

Our initial attempts at vulnerability in story-telling had led many of us to tell very one-sided stories that overly portrayed negative emotions. Our poems felt moody and angry, and some students were turned off by the process. But, as we dug deeper, and I continued to ask for a fuller exploration from myself and my students, we began to process our stories with gentler hands and more patient eyes. We began to understand that humans are complex and so are our stories, that many times pain and joy exist side by side, sometimes even in the same breath. And, as we learned to tell those stories, we began to realize the power of healing and teaching in voicing our poems. We told our stories louder, more assured of their truth and importance. My own stories emerged differently: lighter, rounder, yet still honest-in fact, more honest.

\section{Autobiographical Poem}

We were three small children

We were small

Our hands were small

Our toothbrushes were small 
Our fears were small

Our small was home.

She was always too big for us.

She didn't fit into our playhouse

She was too big to skate on our pond.

She tried anyways

She cracked the ice

She didn't care

Our bodies were too small for the conversations her hands tried to have with our small skins every time the sun was up or the moon was out

She was too big so conversations always felt like fire alarms

She was always crying

Her tears were too big for our teacups

so she put each oversized teardrop in the freezer

then wedged each frozen one under our small tongues

We stretched our lips over iciness smally

We never got candy

Candy would have been small like we were

And we were too small.

We were too small to know she was too big.

So we always left the door unlocked to our small playhouse every time the moon was out

We had a small thought that maybe one day

She'd figure out a way in.

And when she did

Maybe she'd stop crying so much

Maybe she's only crying because she's so cold out there

covered in icy water from a cracked pond

Holding frozen teardrops in hands too big to know that frozen teardrops are not suppers for small children 
If she finds a way in, we thought

We will have a small toothbrush waiting

Come on in, Mom

Our small is home.

Author (2017)

\section{TELL YOUR TRUTH}

Since the beginning of the year, I had spoken to my students about a quote that I hung on the front wall of my classroom from a spoken word piece by educator Clint Smith (2014): "Read critically, write consciously, speak clearly, tell your truth." These words guided me throughout the year. Despite the doubts and unknowns, with love for one another and trust in the process, we arrived at authenticity and empowerment through our reading, writing, and speaking.

When the time came for our first poetry performance, my students were nervous about remembering their lines and how the audience would receive them. I was too. But I was confident that we only needed to do one thing to be successful that night: tell our truth. I let my students know that it didn't matter if they forgot their lines because they were the authors of their own stories, and their hearts and their voices would always know what to do. We only needed to remember why we were speaking in the first place. We spoke to heal, to illuminate, to inspire, to liberate, and to bring together.

Parents, teachers, students, and friends witnessed my students standing as a true community of learners who loved one another and believed in the importance of each of their stories. When students experienced stage fright or became emotional on stage, my students used "pasha" to comfort them. My student emcees spontaneously taught the audience how to participate in our pasha ritual and invited them to send their love and positive energy to our poets, reminding them that to share these stories was an act of bravery. The response from our audience that night was a true testament to the truthtelling my students engaged in. People noted that they had never seen such a loving act before, had never witnessed teenagers truly supporting one another through such vulnerability. Others shared how the poems inspired them or helped them through a similar struggle in which they had felt isolated until they heard the poets sharing their stories. My students and I learned more deeply the power of our voices. We were part of the timeless elevation of human connection through spoken words. Nothing felt more authentic. 


\section{KEEP IT GOING}

As I continue to teach the class with a new group of students, I remind myself of the ongoing nature of learning and transformation. I am careful not to manufacture past successes or expect similar outcomes. I must remain open to the newness of stories as they are embodied in each new student I meet and dialogue with. And I must also challenge myself to be new as a storyteller, not inventing stories or even lesson plans for the sake of entertainment or novelty, but to be still enough in my heart to hear new revelations about who I am and how I fit into this world, and to tell those truths in simple, honest ways.

To other educators struggling to find their own voice and authenticity in work that demands us to be too many things to too many people at once, I invite you to honour your struggle. Name it. Write about it. Give it time. Set it free. It is a necessary struggle. We have a human need to be heard and to feel real. Neither are possible all the time. But there is always a story in that struggle to find our voice and our authenticity. If there is a story, there is a way to honour our experiences and to connect with one another. Learn this with your students. Paolo Freire (1996) wrote that "to speak a true word is to transform the world" (p. 68). The truth is often uncomfortable and elusive, but, when we honor it with our voice and our stories, it is inevitable that we will heal ourselves and transform those around us. Take courage and speak your truth.

\section{NOTES}

1. Included with permission and blessing by the author of the poem. The author also wishes to be identified using her real name.

\section{REFERENCES}

Darder, A. (2011). Teaching as an act of love: Reflections on Paulo Freire and his contributions to our lives and our work. Counterpoints, 418, 179-194.

Duncan-Andrade, J. (2007). Gangstas, wankstas, and ridas: Defining, developing, and supporting effective teachers in urban school. International Journal of Qualitative Studies in Education, 20(6), 617-638.

Freire, P. (1996). Pedagogy of the oppressed. London, United Kingdom: Penguin Books.

Freire, P. (2005). Teachers as cultural workers: Letters to those who dare teach. Cambridge, MA: Westview Press.

Griego, M. (2016) Culture response poem. Unpublished poem.

Smith, C. (2014). Clint Smith: The danger of silence [Video file]. Retrieved from https:// www.ted.com/talks/clint_smith_the_danger_of_silence

Wheatley, M. J. (2002). Turning to one another: Simple conversations to restore hope to the future. San Francisco, CA: Berrett-Koehler. 
JOEY YUNG-JUN LIU is currently an English Learner coordinator and teacher in the Corona Norco district and a Ph.D. in Education student emphasizing in Culture and Curriculum Studies at Chapman University. Her areas of academic interest include decolonizing, place-based, and community-grown education, critical mothering, and oral and visual storytelling. She is currently working on her dissertation study, a participatory film created by and with community members of several decolonizing, place-based, "alternative-autonomous" learning places around the world. In speaking and writing, Joey often still joins her voice to those of her students in the Oral Expressions course, her fellow educator-learners, community-builders, movementmakers, and some of the best poets and human beings she knows. Together, they are passionate about sharing their learnings through speech, art, and poetry to encourage "others" towards collective radical healing and transformation for a more just and equitable future. joey.jun.liu@gmail.com

JOEY YUNG-JUN LIU est coordonnatrice des étudiants apprenant l'anglais et enseignante au sein du district Corona Norco. Elle est aussi doctorante en éducation à la Chapman University en études de la culture et des programmes. Ses recherches portent sur la décolonisation, l'éducation axée sur les lieux ou la communauté, les enjeux liés à la maternité, ainsi que la communication narrative sous des formes orales ou visuelles. À l'heure actuelle, l'auteure travaille sur son mémoire, un projet participatif de création de film par et avec des membres de diverses communautés ayant vécu la décolonisation, et appartenant à des lieux d'apprentissage alternatifs et autonomes situés un peu partout autour du monde. Par la communication orale ou écrite, Joey joint sa voix à celles de ses étudiants au sein du cours Oral Expressions, à celles de ses pairs enseignants-apprenants, ainsi qu'à celles de bâtisseurs communautaires, de créateurs de mouvements, et à certains des meilleurs poètes et êtres humains qu'elle connaît. Ils sont tous passionnés de partager leurs connaissances en recourant au discours, à l'art et à la poésie, et encouragent les " autres » à recourir à une guérison et à une transformation radicales et collectives pour créer un avenir plus juste et équitable. joey.jun.liu@gmail.com 